\title{
TINJAUAN ATAS PERLINDUNGAN HUKUM TERHADAP HAK MENYUSUI ANAK SELAMA WAKTU KERJA DI TEMPAT KERJA BAGI PEKERJA PEREMPUAN
}

\author{
Marlia Eka Putri A.T.
}

Dosen Bagian Hukum Administrasi Negara FH Universitas Lampung

\begin{abstract}
Abstrak
Tujuan penelitian ini adalah untuk mengetahui apakah perlindungan hukum terhadap hak menyusui anak selama waktu kerja di tempat kerja bagi pekerja perempuan telah terjamin. Metode penelitian yang digunakan adalah penelitian normatif dengan bahan pustaka sebagai sumber data. Hasil penelitian menunjukkan bahwa meskipun peraturan perundang-undangannya sudah ada, tetapi perlindungan hukum terhadap hak menyusui anak selama waktu kerja di tempat kerja bagi pekerja perempuan belum terpenuhi. Pengusaha dengan alasan efisiensi, efektivitas kerja, dan penghindaran ekonomi biaya tinggi sangat melalaikan kewajiban yang sudah tercantum dalam perundang-undangan. Seringkali hak pekerja perempuan ini tidak terakomodir oleh peraturan. Upaya pemerintah adalah dengan membuat PP tentang ASI sebagai pelaksana UU No.13/2003 tentang Ketenagakerjaan dan UU No.36/2009 tentang Kesehatan, yang memuat sanksi bagi pengusaha yang melalaikan kewajiban untuk memenuhi hak pekerja perempuan untuk menyusui anak selama waktu kerja di tempat kerja, maupun di tempat-tempat umum seperti rumah sakit, bandar udara, perbelanjaan, dan sebagainya, baik sanksi pidana penjara, denda, maupun pencabutan izin usaha.
\end{abstract}

Kata Kunci : ASI, perlindungan hukum, hak pekerja perempuan, menyusui.

\section{PENDAHULUAN}

Anak adalah generasi penerus bangsa. The founding father kita, Ir. Soekarno, pernah menyatakan bahwa kekuatan sebuah bangsa dapat diukur dari generasi mudanya. Oleh sebab itu, diperlukan generasi yang sehat, kuat, dan hal tersebut dapat dimulai sejak dini dengan pemenuhan hak anak diantaranya adalah pemberian Air Susu Ibu (ASI) eksklusif.

ASI merupakan hak anak yang wajib diberikan orangtua. ASI merupakan makanan bayi yang terbaik, yang tidak akan dapat digantikan oleh makanan ataupun minuman manapun, karena ASI mengandung zat gizi yang paling tepat, lengkap dan selalu menyesuaikan dengan kebutuhan bayi setiap saat. ASI memiliki zat-zat gizi yang bernilai tinggi yang dibutuhkan untuk pertumbuhan dan perkembangan saraf otak bayi, memiliki zat-zat kekebalan terhadap penyakit, dan menguatkan ikatan emosional antara ibu dan anak (Amanda Tasya, 2009).

Perempuan yang bekerja pada masa sekarang ini telah menjadi arus utama di banyak industri, seperti sektor perkebunan, pabrik rokok, ritel moderen, industri kerajinan dan mebel, pabrik makanan, elektronik, tekstil dan lain-lain. Selain 
dipandang rajin dan telaten, perempuan dinilai penurut sehingga banyak dipekerjakan hampir di setiap lini industri. Pekerja perempuan diperlakukan sama dengan pekerja laki-laki.

Paradigma kesetaraan jender sekarang menempatkan kaum perempuan memiliki kedudukan dan peran yang tidak kalah dengan lakilaki. Pekerja perempuan dituntut untuk meningkatkan kemampuan dan kapasitas kerja secara maksimal, tanpa mengabaikan kodratnya sebagai wanita. Namun, dari segi riwayat kesehatan, pekerja perempuan diperlakukan berbeda dari laki-laki terkait dengan kodratnya untuk melahirkan dan menyusui.

Secara fisiologis, perempuan dikodratkan untuk melahirkan dan menyusui anaknya, meski kodrat ini dapat memengaruhi kelancaran tugas yang menjadi tanggung jawabnya. Namun, dari sisi kemampuan untuk mencapai prestasi, tidak ada perbedaan antara laki-laki dan perempuan yang bekerja. Kondisi tersebut sering menimbulkan perlakuan diskriminatif terhadap pekerja perempuan.

ASI merupakan hak setiap anak di dalam tumbuh kembangnya. Berdasarkan konsep Pengarusutamaan Hak Anak (PUHA) yang diprogramkan oleh Kementerian Negara Pemberdayaan Perempuan, setiap anak berhak atas:

a. Hak kelangsungan hidup dan tumbuh kembang.

b. Semua hak yang diakui dan terkandung di dalam Konvensi Hak Anak harus diberlakukan kepada setiap anak tanpa adanya diskriminasi c. Kepentingan yang terbaik bagi anak harus menjadi pertimbangan yang utama

d. Penghargaan terhadap pendapat anak.

Di banyak negara di dunia, selalu ada hukum yang menjamin pekerja perempuan untuk dapat menyusui bayinya selama bekerja maupun memerah ASI selama waktu kerja di tempat kerja. Namun masih ada pula beberapa negara yang belum memiliki jaminan untuk itu, yaitu negara-negara dimana memerah ASI maupun menyusui bayi bukanlah merupakan suatu kebiasaan yang sifatnya umum.

Berdasarkan

Konvensi

International Labour Organization (ILO) Nomor 183/2000, negara harus mendukung \& menjamin aktivitas hak ibu menyusui saat bekerja agar dapat terus memberikan ASI eksklusif selama 6 bulan meskipun harus bekerja. Di Indonesia sendiri terdapat Undang-Undang Nomor 13 Tahun 2003 yang memberikan perlindungan terhadap tenaga kerja untuk menjamin hak-hak dasar pekerja, dan menjamin kesamaan kesempatan serta perlakuan tanpa diskriminasi untuk mewujudkan kesejahteraan pekerja dan keluarganya dengan tetap memperhatikan perkembangan kemajuan dunia usaha. Perlindungan terhadap tenaga kerja wanita khususnya diatur dalam Pasal 76 sampai dengan Pasal 84.

Hak menyusui untuk wanita pekerja telah diatur oleh Pasal 83 UU No.13/2003. Namun dalam kenyataannya masih belum ada jaminan atas perlindungan hak menyusui anak bagi pekerja perempuan. Bahkan sering sekali hak pekerja perempuan yang menjadi kewajiban pengusaha ini terabaikan. 
Pekerja perempuan hanya diberikan waktu 3 (tiga) bulan untuk cuti melahirkan, padahal kenyataannya ASI eksklusif menurut UU No.36/2009 tentang Kesehatan adalah 6 (enam) bulan.

Kesempatan menyusui eksklusif semestinya didapat oleh pekerja perempuan dengan cara diperbolehkannya mereka menyusui bayi atau memerah ASI pada waktu kerja di tempat kerja, selama tidak mengganggu kegiatan usaha. Namun pengusaha sering sekali menganggap bahwa hal tersebut akan berimplikasi pada ekonomi biaya tinggi dan mengganggu iklim usaha, sehingga daya saing industri menjadi rendah.

\section{PEMBAHASAN}

Perempuan menjadi buruh adalah gejala global. Peningkatan jumlah buruh perempuan baik dalam sektor formal maupun informal, naik sekitar 40\%. Meskipun demikian, buruh perempuan jarang mendapat perlakuan yang sama dengan buruh laki-laki baik dari segi upah, susila, maupun maternitas seperti reproduksi, kehamilan, termasuk menyusui (Rita Olivia Tambunan, 2007).

Buruh perempuan cenderung lebih pasif dan menerima keputusan perusahaan berkaitan dengan rasionalisasi seperti mengurangi waktu kerja, merumahkan pekerja, PHK, maupun menghindari kewajiban terhadap pemenuhan hak bagi pekerja perempuan. Perusahaan cenderung merekrut pekerja perempuan yang muda belia untuk mengganti pekerja perempuan yang sudah tua maupun yang sudah berkeluarga, sehingga kesempatan kerja bagi pekerja perempuan berkeluarga semakin sempit.
(Hidayat Muharam, 2006). Hal ini menyebabkan perlunya perlindungan hukum bagi pekerja perempuan.

Perlindungan hukum bagi pekerja perempuan sendiri merupakan penjagaan agar pekerja melakukan pekerjaan yang layakbagi kemanusiaan dan tidak hanya ditujukan terhadap pihak majikan yang hendak memeras tenaga buruh, tetapi ditujukan kepada pekerja itu sendiri, bilamana pekerja misalnya hendak memboroskan tenaganya dengan tidak mengindahkan kekuatan jasmani dan rohaninya (Iman Soepomo, 2005).

Perlindungan hukum atas hak pekerja perempuan untuk menyusui anak selama waktu kerja di tempat kerja diatur di dalam peraturan perundang-undangan.

\subsection{Hak Pekerja Perempuan Berdasarkan UU No.13/2003}

Terdapat beberapa pasal yang menjamin hak pekerja perempuan dalam UU No.13/2003, antara lain:

a. Pasal 76

"Pekerja perempuan berumur di bawah 18 tahun dilarang dipekerjakan antara jam 23.0007.00. Pengusaha dilarang mempekerjakan wanita hamil yang menurut keterangan dokter membahayakan kesehatan dan keselamatan diri maupun kandungannya jika bekerja antara jam 23.00-07.00.

Pengusaha yang mempekerjakan wanita antara jam 23.00-07.00 wajib:

1) Memberi makanan dan minuman bergizi.

2) Menjaga keamanan dan kesusilaan di tempat kerja.

3) Wajib menyediakan angkutan antar jemput bagi pekerja 
wanita yang berangkat dan pulang kerja antara jam 23.00-05.00"

b. Pasal 81

"Pekerja perempuan dalam masa haid, merasa sakit dan melapor pada pengusaha, TIDAK WAJIB bekerja pada hari 1 dan 2 pada waktu haid."

c. Pasal 82

"Pekerja perempuan berhak cuti 1,5 bulan sebelum melahirkan dan 1,5 bulan setelah melahirkan menurut perhitungan dokter/bidan. Pekerja perempuan yang mengalami keguguran berhak cuti 1,5 bulan sesuai surat keterangan dokter/bidan."

d. Pasal 83

"Pekerja wanita yang anaknya masih menyusui harus diberi kesempatan untuk menyusui anaknya jika hal itu harus dilakukan selama waktu kerja."

e. Pasal 84

"Setiap pekerja wanita yang menggunakan hak waktu istirahat sesuai pasal 79, 80 dan 82 berhak mendapatkan upah penuh."

Berdasarkan ketentuan tersebut, UU No.13/2003 telah memberikan apresiasi terhadap hakhak pekerja perempuan. Akan tetapi, ketentuan-ketentuan tersebut masih bersifat global. Dalam Pasal 83 pekerja perempuan yang anaknya masih menyusu harus diberi kesempatan sepatutnya untuk menyusui anaknya jika hal itu harus dilakukan selama waktu kerja. Ketentuan ini dimaksudkan untuk menjamin agar pekerja perempuan dapat memenuhi kewajibannya sebagai ibu untuk memberi ASI walaupun harus bekerja untuk membantu mencari nafkah bagi keluarganya.
Namun, tidak ada penjelasan lebih detail dalam undang-undang mengenai hak pengasuhan anak di atas usia menyusui dengan membawa anak ke tempat kerja, saranaprasarana yang wajib dipenuhi pengusaha, serta sanksi apabila pengusaha tidak mau menyediakan fasilitas menyusui di tempat bekerja.

\subsection{Peraturan Perundang- undangan yang Memberikan Perlindungan Hukum Atas Hak Menyusui Anak Selama Waktu Kerja Di Tempat Kerja Bagi Pekerja Perempuan}

Paraturan perundang-undangan yang mengatur tentang hak pekerja perempuan untuk menyusui anak tersebar dalam bidang ketenagakerjaan, kesehatan, maupun pemberdayaan perempuan.

a. Pasal 10 Konvensi ILO Nomor $183 / 2000$ mengenai Ibu menyusui menyebutkan :

1) Perempuan harus diberi hak istirahat harian atau pengurangan jam kerja harian untuk menyusui anaknya.

2) Berapa lama istirahat menyusui atau pengurangan jam kerja harian ini akan diberikan, banyaknya dalam sehari, lamanya tiap-tiap istirahat dan cara-cara pengurangan jam kerja harian ini diatur berdasarkan hukum dan kebiasan nasional. Istirahat dan pengurangan jam kerja harian ini harus dihitung sebagai jam kerja dan dibayar."

Negara anggota wajib menjamin hak ibu menyusui untuk tidak bekerja. Indonesia baru mengadopsi peraturan ini, 
namun belum meratifikasinya. Pemberian ASI eksklusif ditentukan selama 6 (enam) bulan, sedangkan lamanya cuti yang diperkenanakan oleh undang-undang hanya 3 bulan.

b. Pasal 49 ayat (2) UU No.49/1999 tentang Hak Asasi Manusia menyebutkan bahwa :

"Wanita berhak untuk mendapatkan perlindungan khusus dalam pelaksanaan pekerjaan atau profesinya terhadap hal-hal yang dapat mengancam keselamatan dan atau kesehatannya berkenaan dengan fungsi reproduksi wanita."

Yang dimaksud dengan "perlindungan khusus terhadap fungsi reproduksi" disini adalah pelayanan kesehatan yang berkaitan dengan haid, hamil, melahirkan dan termasuk juga pemberian kesempatan untuk menyusui anak.

c. Pasal 22 UU No. 23/2002 tentang Perlindungan Anak menggariskan bahwa :

"Negara \& pemerintah berkewajiban dan bertanggung jawab memberikan dukungan sarana dan prasarana dalam penyelenggaraan perlindungan anak".

Dalam penjelasan pasal di atas dinyatakan bahwa sarana dan prasarana itu salah satunya adalah ketersediaan ruang menyusui.

\section{d. Pasal 128 UU No.39/2009} tentang Kesehatan
1) Setiap bayi berhak mendapatkan ASI eksklusif sejak dilahirkan selama 6 (enam) bulan, kecuali atas indikasi medis

2) Selama pemberian ASI, pihak keluarga, pemerintah, pemerintah daerah dan masyarakat harus mendukung ibu bayi secara penuh dengan penyediaan waktu dan fasilitas khusus

3) Penyediaan fasilitas khusus sebagaimana dimaksud pada ayat (2) diadakan di tempat kerja dan di tempat sarana umum"

e. Pasal 83 UU No. 13/2003 tentang Ketenagakerjaan

Pekerja/buruh perempuan yang anaknya masih menyusui harus diberi kesempatan sepatutnya untuk menyusui anaknya jika hal itu harus dilakukan selama waktu kerja."

Dalam pasal tersebut, jelas dinyatakan bahwa pekerja perempuan yang anaknya masih menyusui harus diberi kesempatan sepatutnya untuk menyusui anaknya jika hal itu harus dilakukan selama waktu kerja. Yang dimaksud dengan kesempatan yang patut disini adalah waktu yang diberikan kepada pekerja untuk menyusui bayinya, serta ketersediaan tempat yang sesuai untuk melakukan kegiatan tersebut.

Pengertian menyusui disini adalah luas, yaitu baik menyusui secara langsung maupun tidak langsung (dengan memerah). Namun, sayangnya peraturan tersebut tidak disertai dengan sanksi yang memadai bagi 
perusahaan yang melanggarnya, dan karenanya hingga saat ini belum masih banyak pekerja perempuan yang tidak dapat melaksanakan haknya untuk memberikan ASI selama ia berada dalam jam kerja.

f. Pasal 2 Peraturan Bersama Menteri Negara Pemberdayaan Perempuan, Menteri Tenaga Kerja dan Transmigrasi dan Menteri Kesehatan No. 48/MEN.PP/XII/2008, PER.27/ MEN/XII/2008 dan 1177/ MENKES/PB/XII/2008 tahun 2008 tentang Peningkatan Pemberian Air Susu Ibu Selama Waktu Kerja di Tempat Kerja

Tujuan peraturan bersama ini adalah :

1) memberi kesempatan kepada pekerja perempuan untuk memberikan atau memerah ASI selama waktu kerja dan menyimpan ASI perah untuk diberikan kepada anaknya

2) memenuhi hak pekerja perempuan untuk meningkatkan kesehatan ibu dan anaknya

3) memenuhi hak anak untuk mendapatkan ASI guna meningkatkan gizi dan kekebalan anak dan

4) meningkatan kualitas sumber daya manusia sejak dini.

Peraturan Bersama ini hanya bersifat koordinasi, meliputi pembinaan, pelatihan, soasialisasi, dan pemantauan, akan tetapi belum menyertakan adanya sanksi bagi pengusaha yang tidak mengindahkan hak pekerja perempuan untuk menyusui selama waktu kerja di tempat kerja.
Peraturan perundang-undangan telah mengamanatkan kepada pemerintah maupun pengusaha akan hak-hak pekerja perempuan untuk menyusui anak di tempat kerja selama bekerja. Ini merupakan bentuk jaminan negara \& pemerintah bahwa ada pengakuan akan hak tersebut, serta ada aspek perlindungan hukum di dalamnya.

\subsection{Kewajiban Pengusaha dan Peran Pemerintah dalam Perlindungan Hukum Atas Hak Menyusui Anak Selama Waktu Kerja Di Tempat Kerja Bagi Pekerja Perempuan}

Meskipun peraturan perundang -undangan telah menentukan hak pekerja perempuan untuk dapat terus menyusui bayinya selama waktu kerja di tempat kerja, namun hal tersebut masih sulit untuk diterapkan. Konsekuensi dari Pasal 83 UU No.13/2003 adalah kewajiban bagi pengusaha untuk memberi kesempatan dan fasilitas kepada ibu bekerja untuk memberikan/memerah ASI selama waktu kerja dan menyimpan ASI perah tersebut.

Pengusaha wajib memberikan waktu bagi pekerja perempuan untuk menyusui bayi atau mengumpulkan susu dan disimpan sementara, sehingga wajib menyediakan tempat khusus berupa pojok ASI dan lemari es untuk menyimpan susu perahan, sebab ASI perah harus disimpan dalam suhu rendah agar dapat bertahan lama sampai dapat diberikan kepada bayi di rumah.

Pengusaha berat memenuhinya karena khawatir pekerjaan akan terhambat, disertai biaya tambahan untuk menyediakan sarana-prasarana fasilitas ASI seperti lemari es, ruang 
khusus sebagai pojok ASI, tambahan biaya listrik, dan sebagainya (Kompas, 29 September 2011). Tidak menutup pula kemungkinan diharuskan menyediakan tempat penitipan bayi serta petugasnya. Pengusaha yang tidak mengindahkan dapat dikenai sanksi administrasi dan dapat dicabut izin usahanya, namun jenis sanksi dan prosedur pengenaannya belum diatur lebih jauh dalam peraturan perundangundangan.

Peran pemerintah dalam perlindungan hak ini adalah dengan tengah disiapkannya Peraturan Pemerintah tentang ASI (PP-ASI) sebagai amanat UU No.36/2009 yang akan mengatur tentang pemberian ASI eksklusif bagi bayi, pembatasan susu formula, termasuk pembatasan pengiklanan produk, dan pembentukan ruangan menyusui disetiap tempat bekerja, sarana kesehatan, perkantoran dan fasilitas umum untuk menyediakan pojok ASI. Bila hal ini tidak dilaksanakan maka para pihak yang menghalangi para ibu memberikan ASI Eksklusif dapat dipidana penjara paling lama 1 (satu) tahun dan denda paling banyak Rp100.000.000,00 (seratus juta rupiah) sesuai dengan ketentuan Pasal 200 UU No.36/2009.

\section{PENUTUP}

\subsection{Simpulan}

Perlindungan hukum terhadap hak menyusui anak selama waktu kerja di tempat kerja bagi pekerja perempuan belum terjamin sepenuhnya, meskipun peraturan perundang-undangan sudah ada. Pengusaha dengan alasan efisiensi, efektivitas kerja, dan penghindaran ekonomi biaya tinggi sangat melalaikan kewajiban yang sudah tercantum dalam perundangundangan. Seringkali hak pekerja perempuan ini tidak terakomodir oleh peraturan. Upaya pemerintah adalah dengan membuat PP ASI sebagai pelaksana UU No.36/2009, yang memuat sanksi bagi pengusaha yang melalaikan kewajiban untuk memenuhi hak pekerja perempuan untuk menyusui anak selama waktu kerja di tempat kerja, maupun di tempat-tempat umum seperti rumah sakit, bandar udara, perbelanjaan, dan sebagainya.

\subsection{Saran}

Sebaiknya pengusaha menerapkan kebijakan yang ramah terhadap pekerja perempuan yang menyusui, dengan menyediakan ruang menyusui, memberikan waktu untuk memerah/menyusui langsung bila menyusui harus dilakukan selama waktu kerja. Merupakan sesuatu hal yang ilegal apabila mendikriminasikan pekerja perempuan hanya karena mereka menyusui. Apabila pekerja laki-laki diperbolehkan untuk merokok di tempat kerja pada waktu istirahat atau sesudah beribadah, maka adalah hak pekerja perempuan untuk menyusui anaknya atau memerah ASI pada waktu yang sama.

\section{DAFTAR PUSTAKA}

Muharam, Hidayat, Hukum
Ketenagakerjaan
Pelaksanaannya di Indonesia,
PT Citra Aditya Bakti,
Bandung, 2006.
Tambunan, Rita Olivia, Buruh
Perempuan Indonesia dan
Gejala Globalisasi (Jurnal
Perempuan No.56), Yayasan
Jurnal Perempuan, Jakarta,
2007.


Tasya, Amanda, Hak Ibu Menyusui di Indonesia, Lembaga Advokasi Asosiasi Ibu Menyusui Indonesia, 2011.

Pandya, Gunjan, Hak Menyusui Ibu di Indonesia, 2011.

Soekanto, Soerjono, Pengantar Penelitian Hukum, UI Press, Jakarta, 1986.

Soepomo, Iman, Hukum Perburuhan (revisi 2003). Djambatan, Jakarta, 2003.

Pengarusutamaan Hak Anak (PUHA), Kementerian Negara Pemberdayaan Perempuan

Konvensi ILO No.183/2000 mengenai Ibu Menyusui

UU No.49/1999 tentang Hak Asasi Manusia

UU No. 23/2002 tentang Perlindungan Anak

UU No. 13/2003 tentang Ketenagakerjaan

UU No.39/2009 tentang Kesehatan

Peraturan Bersama Menteri Negara Pemberdayaan Perempuan, Menteri Tenaga Kerja dan Transmigrasi dan Menteri Kesehatan No. 48/MEN.PP/XII/2008, PER.27/MEN/XII/2008 dan 1177/MENKES/ PB/XII/2008 tahun 2008 tentang Peningkatan Pemberian Air Susu Ibu Selama Waktu Kerja di Tempat Verja

Rancangan Peraturan Pemerintah tentang Air Susu Ibu (ASI).

Kompas, RPP ASI Masih Di Kementerian Perdagangan, Kamis, 29 September 2011. 